\title{
The Role Played by Blocking System over North America on the Development of Hurricane Ophelia over North Atlantic Ocean
}

\author{
Yehia Hafez ${ }^{*}$, Abdulhaleem Labban \\ Department of Meteorology, King Abdulaziz University, Jeddah, KSA \\ Email: *ysalam@kau.edu.sa, alabban@kau.edu.sa
}

How to cite this paper: Hafez, Y., \& Labban, A. (2018). The Role Played by Blocking System over North America on the Development of Hurricane Ophelia over North Atlantic Ocean. Journal of Geoscience and Environment Protection, 6, $1-20$.

https://doi.org/10.4236/gep.2018.612001

Received: October 24, 2018

Accepted: December 1, 2018

Published: December 4, 2018

Copyright $\odot 2018$ by authors and Scientific Research Publishing Inc. This work is licensed under the Creative Commons Attribution International License (CC BY 4.0).

http://creativecommons.org/licenses/by/4.0/

(c) (i) Open Access

\begin{abstract}
As one of very rare and unusual tracks of hurricane Ophelia, it exists over the North Atlantic Ocean during the period of 9-17 October 2017. The present work investigates the role played by blocking system over North America on the development of hurricane Ophelia. The 6-hour daily data of NCEP/NCAR reanalysis composites for the meteorological parameters are used. The meteorological elements used in the present work are (geopotential height and meridional wind components at 500-hpa level). The domain of this data is the northern hemisphere domain. Moreover, the 6-hour data on the surface pressure at the center of hurricane Ophelia and its maximum wind through the period (9-17 October) have been used. The time series, anomaly and correlation coefficient methods have been used to analyze the meteorological data. The results revealed that the persistence of blocking high system over the North America during the period of 9-17 October 2017 controls the development, strength, and the track of hurricane Ophelia over the North Atlantic Ocean.
\end{abstract}

\section{Keywords}

Blocking System, North America, North Atlantic Ocean, Hurricane Ophelia

\section{Introduction}

Hurricane Ophelia developed over the North Atlantic Ocean on 9 October 2017. It was considered as the easternmost major hurricane (Category 3 intensity) according to Saffir-Simpson scale of hurricanes. The hurricane Ophelia initiated near the west of the Azores as a tropical storm. It dissipated over Ireland and United Kingdom on 17 October 2017 as an extratropical storm. Three deaths 
occurred in Ireland directly attributed to Ophelia. The total losses from the storm estimated at US\$ 1.18 billion in Ireland and around US\$ 13 million in the United Kingdom (Moore, 2018). Figures 1-3 illustrate the satellite images of the development, dissipation and the track of hurricane Ophelia. This hurricane is one of very rare and unusual tracks of hurricanes in the North Atlantic Ocean. This storm steadily strengthened over the first days before becoming a hurricane on 11 October. After becoming a Category 2 hurricane and turning in intensity for a day, Ophelia intensified into a major hurricane (of category 3) on 14 October, south of the Azores. Archipelago is near the Azores Savard from a severe weather with strong winds and heavy rainfall. After achieving peak intensity, Ophelia began sapping as it accelerated over progressively colder waters to its northeast towards Ireland and Great Britain (Stewart, 2018). However, there are several literatures studying the teleconnection between the existences of Atlantic hurricanes and blocking over the northern hemisphere (McTaggart-Cowan et al., 2006;

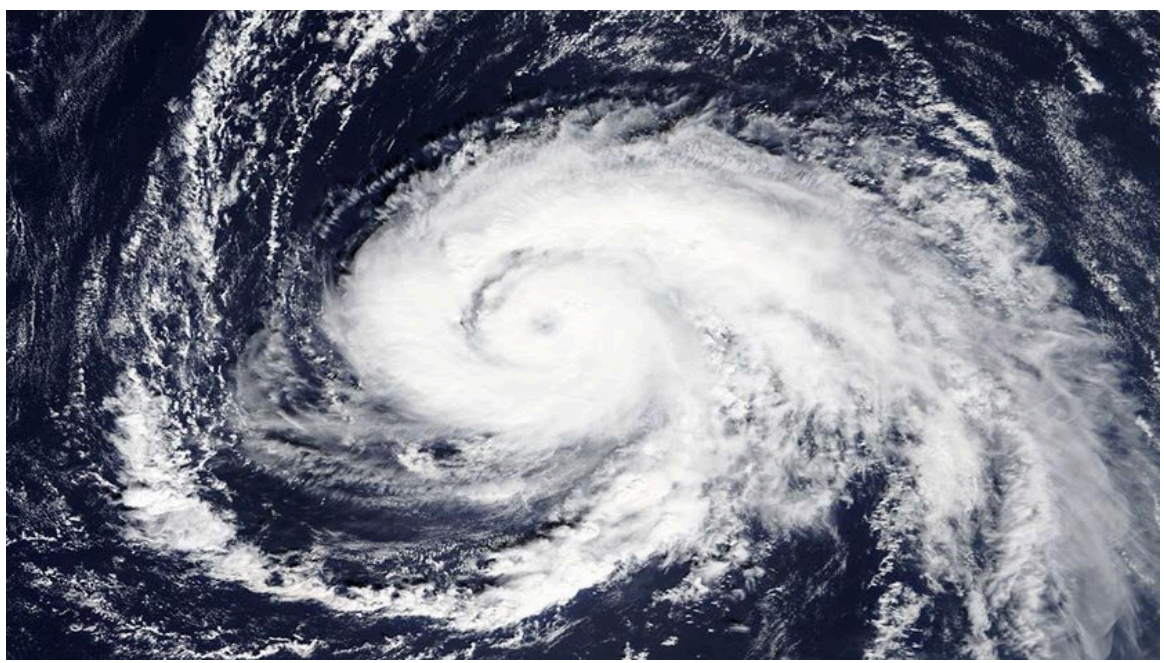

Figure 1. MODIS satellite image of Ophelia on Friday morning, October 13, 2017. At the time, Ophelia was a Category 2 storm with 87 knot winds. Image credit: NASA.

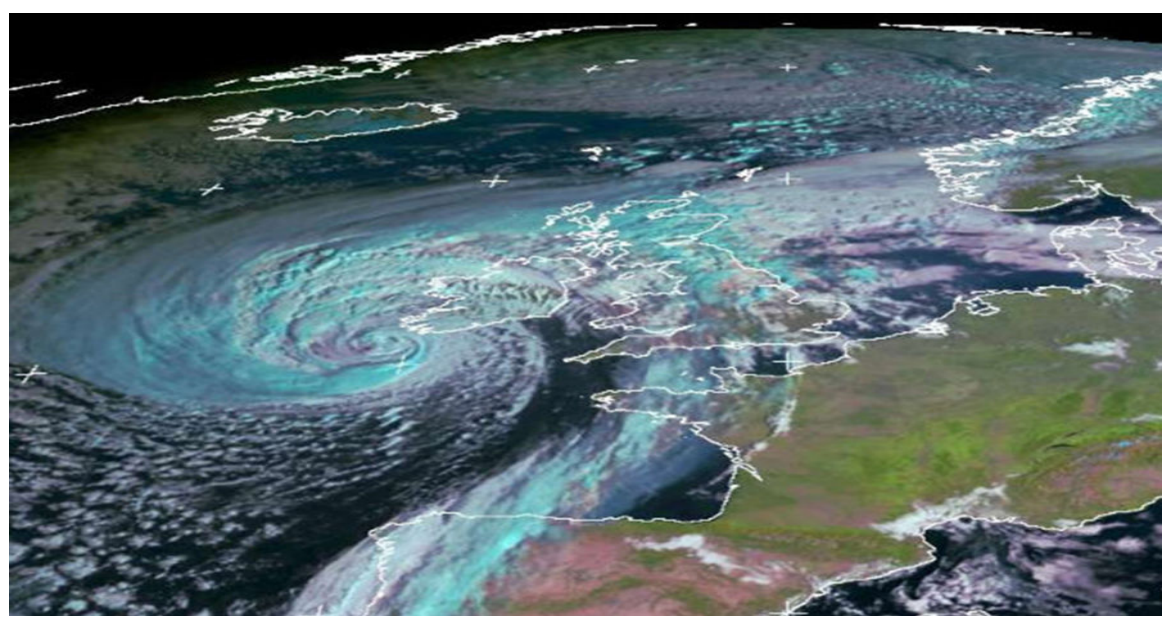

Figure 2. Landfall of Hurricane Ophelia over Ireland Meteosat satellite capture by university of Dundee satellite reserving station at 9:00 GMT 16 October 2017. 


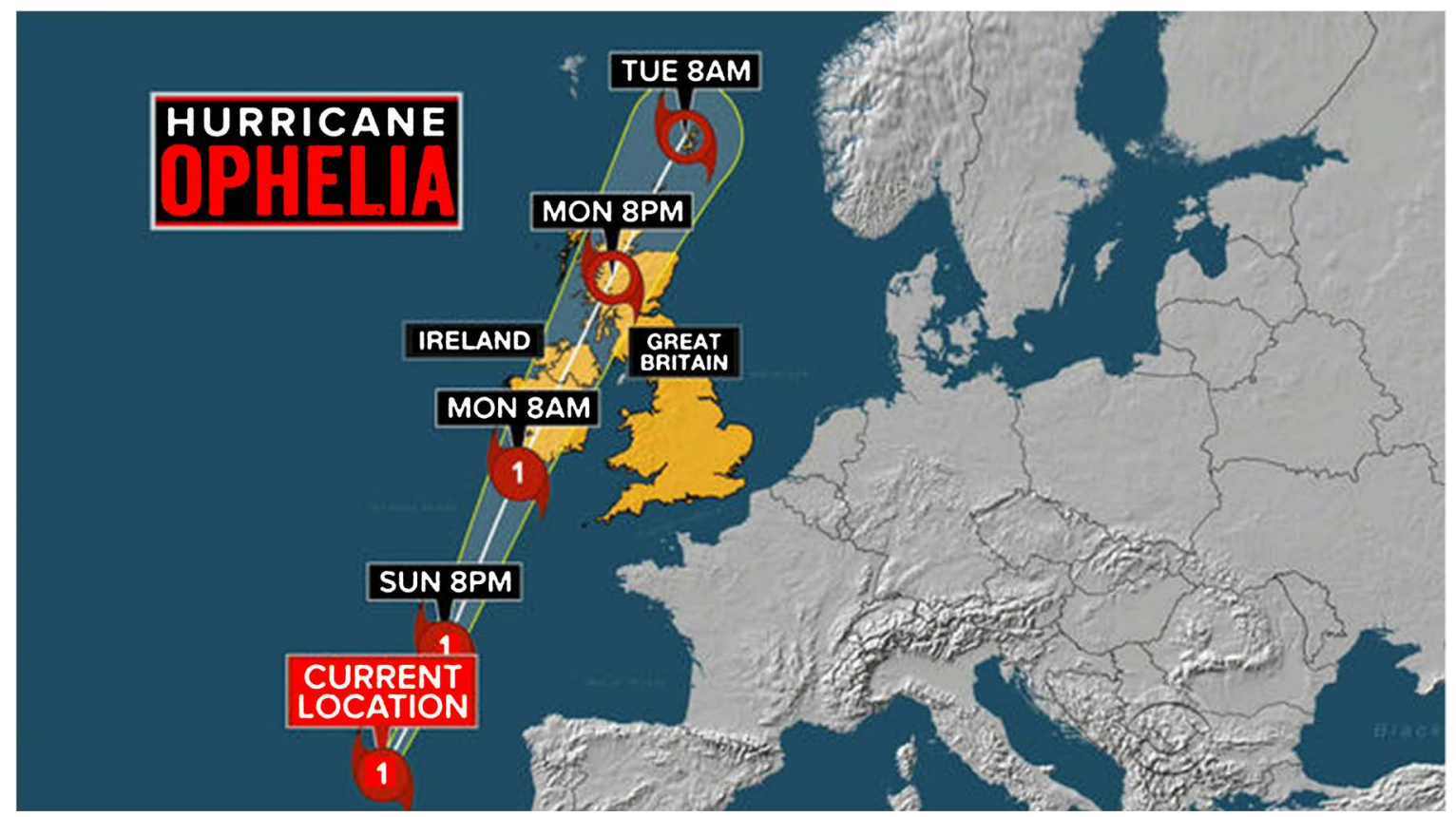

Figure 3. The track of hurricane Ophelia [Source: US National Hurricane Center].

Pezza \& Simmonds, 2006; Hafez, 2008; Hafez, 2011; Mattingly et al., 2014). The blocking systems control the atmospheric circulation and weather conditions in the northern hemisphere (Treidl et al., 1981; Park \& Ahn, 2014; Whan et al., 2016; Brunner \& Steiner, 2017). In fact, blocking high episodes have a great impact on the weather and climate of several areas because they are depicted by the sudden change in the atmospheric flow, affecting the normal synoptic systems (Sinclair, 1996; Wiedenmann et al., 2002; Renwick, 2005; Hafez, 2012; Hafez \& Almazroui, 2013; Hafez \& Almazroui, 2016). However, there are several criteria for blocking definition. The Rex definition of blocking is defined the blocking episodes by using of synoptic charts and putting quantitative conditions (Rex, 1950a, 1950b, 1951). Dole (1982) defines the blocking episode using of numeric conditions. The present work aims to study the anomaly of geopotential height and meridional wind component over the North America and Atlantic Ocean during the period of hurricane Ophelia; moreover study the correlation relation between them and the characteristics of hurricane Ophelia (development, strength, track); finally, uncover the teleconnection between the blocking system persist over North America and the existing, developments and extreme track of hurricane Ophelia over the northern Atlantic Ocean through the period of 9-17 October 2017.

\section{Data and Methodology}

The 6-hour data of NCEP/NCAR reanalysis composites for the meteorological parameters are used. The NCEP/NCAR Reanalysis 1 project is using a state-of-the-art analysis/forecast system to perform data assimilation using past data from 1948 to the present. A large subset of this data is available from PSD 
in its original 4 times daily format and as daily averages. The meteorological elements used in the present work are geopotential height and meridional wind components at 500-hpa level. The domain of the present study is the northern hemisphere including the area over the North America and north Atlantic regions. The NCEP/NCAR gridded for these meteorological data are with temporal interpolation of 2.5-degree latitude $\times 2.5$-degree longitude. The period of this data is the period of hurricane Ophelia (9-17 October 2017). The long-term mean for 6-hour values of the meteorological parameters taken over the period (1981-2010). This data supported from the site of NOAA/OAR/ESRL PSD, Boulder, Colorado, USA and according to (Kalnay et al., 1996). In addition to that, the 6-hour of meteorological elements of hurricane Ophelia surface pressure and wind speed used in the present study (Stewart, 2018). The data sets analyzed using time series, anomaly methodology and linear correlation coefficient techniques (Hafez \& Almazroui, 2013). The correlation analysis follows the Pearson correlation method according to Kendall and Stuart (1973). Moreover, the satellite images of hurricane Ophelia and its track has used.

\section{Blocking Criteria}

To clarify the role of blocking system on the development, hurricane Ophelia the definition of blocking episode needed first. In fact, there are several definitions of blocking systems. Some of them are according to the synoptic criteria and other definitions according to numeric criteria. The synoptic and numeric criteria of the blocking formation systems are defined by Rex (1950a, 1950b, 1951), Namias (1964), Dole and Gordon (1983) and Dole (1986). For the purpose of the present study, the blocking system defined based on criteria of Rex (1950a, 1950b) and Dole (1986). In this work, the definition using synoptic charts side by side to anomaly conditions of geopotential height conditions at the $500-\mathrm{hPa}$ level. These criteria have basic conditions such as the westerly air current aloft must split to two distinct branches. This splitting must be northern latitude of $30^{\circ} \mathrm{N}$. The using of these synoptic criteria has advantage for clarify the synoptic situation of the main westerly air current aloft and initiation of the blocking case in the atmospheric air weather charts. For numeric, quantitatively, the anomaly in geopotential height value at $500 \mathrm{hPa}$ level must be more than $+100 \mathrm{~m}$ for a high pressure flag for several longitudes. In addition to that, the anomaly is less or equal $(-100 \mathrm{~m})$ for low pressure flag for several longitudes. Moreover, these conditions must persist more than or equal to five continues days. This numeric method has exact quantitative values for blocking detection.

\section{Results and Discussion}

\subsection{Analysis of the Meteorological Elements of Hurricane Ophelia (9-17 October 2017)}

Time series analysis has been used to analysis the variation of surface pressure at the center of hurricane Ophelia and the maximum wind through the period 
(9-17 October 2017). The results revealed that:

1) The surface pressure gradually decreased from 1008 hpa on 9 October 0000 UTC to reach to 966 hpa on 13 October 0600 UTC. After that, it has slightly increased to reach 974 to 13 October 1200 UTC. The pressure values decrease again to record $963 \mathrm{hpa}$ on 14 October 0600 UTC. Through the period (14 October 1200 UTC to 15 October 1800 UTC), the pressure is a constant value of 959 hpa. The surface pressure become increasing sharply from 959 hpa on 16 October 1200 UTC to reach its maximum value $997 \mathrm{hpa}$ on the dissipation of the hurricane Ophelia on 17 October 1800 UTC. The variability of surface pressure at the center of the hurricane is completely clear in Table 1 and Figure 4.

2) The wind strength analysis clarifies that the hurricane Ophelia has seven stages of initiation on 9 October to the dissipation on 17 October 2017. It developed as a tropical storm on 9 October 0000 UTC with maximum wind 35 knots. This stage continues until 11 October 1200 UTC to wind reached to 60 knots. After that time, it becomes a hurricane of category 1 according to the Saffir-Simpson hurricane scale and the wind reached to 80 knots on 12 October 1200 UTC. The Ophelia reached to category 2 on 12 October 1800 UTC and stay in this category to 14 October 0600 UTC and record on it a maximum wind of 95 knots. It has reached to category 3 on 14 October 1200 UTC and stay shortly to 1800 UTC through that day with maximum wind recorded 100 knots. This wind value is the highest value of wind of hurricane Ophelia through its life period. On 15 October 0000 UTC hurricane Ophelia weakness to category 2 and the maximum wind reached to 85 knots on 15 October 1200 UTC. The weakness of hurricane Ophelia continues to reach to category on and the maximum wind record is 65 knots on 16 October 1200 UTC. Finally, it becomes an extratropical storm and reach to the dissipation stage on 17 October 1800 UTC within the wind record is 40 knots. The wind values and its variations clarified in Table 1 and Figure 5. It is clear that the highest wind speed is nearest to the point of

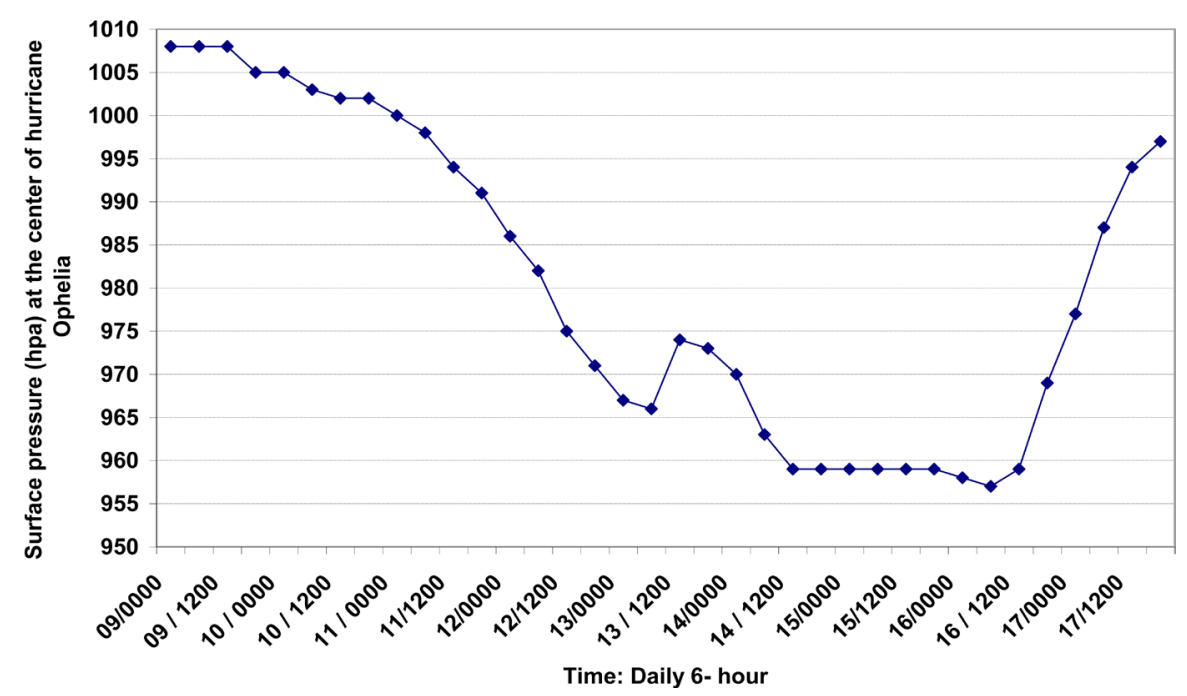

Figure 4. 6-hour surface pressure (hpa) at the center of hurricane Ophelia through the period (9-17 October 2017). 
Table 1. The characteristics of hurricane Ophelia from 09 October to 17 October 2017 each 6 hours.

\begin{tabular}{|c|c|c|c|c|c|}
\hline $\begin{array}{l}\text { Date/Time } \\
\text { (UTC) }\end{array}$ & Latitude $\left({ }^{\circ} \mathrm{N}\right)$ & $\begin{array}{c}\text { Longitude } \\
\left({ }^{\circ} \mathrm{W}\right)\end{array}$ & Pressure (mb) & $\begin{array}{l}\text { Wind Speed } \\
\quad(\mathrm{kt})\end{array}$ & $\begin{array}{c}\text { Hurricane } \\
\text { Category }\end{array}$ \\
\hline 09/0000 & 30.5 & 40 & 1008 & 35 & \multirow{11}{*}{ Tropical storm } \\
\hline $09 / 0600$ & 30.9 & 40 & 1008 & 35 & \\
\hline $09 / 1200$ & 31.3 & 40 & 1008 & 35 & \\
\hline $09 / 1800$ & 31.7 & 39.6 & 1005 & 40 & \\
\hline $10 / 0000$ & 32 & 39.1 & 1005 & 40 & \\
\hline $10 / 0600$ & 31.9 & 38.8 & 1003 & 45 & \\
\hline $10 / 1200$ & 31.6 & 38.5 & 1002 & 45 & \\
\hline $10 / 1800$ & 31.3 & 38.2 & 1002 & 45 & \\
\hline $11 / 0000$ & 30.9 & 37.8 & 1000 & 50 & \\
\hline $11 / 0600$ & 30.4 & 37.2 & 998 & 55 & \\
\hline $11 / 1200$ & 30 & 36.7 & 994 & 60 & \\
\hline $11 / 1800$ & 29.8 & 36.2 & 991 & 65 & \multirow{4}{*}{ Category 1} \\
\hline $12 / 0000$ & 29.9 & 35.8 & 986 & 70 & \\
\hline $12 / 0600$ & 30.2 & 35.7 & 982 & 75 & \\
\hline $12 / 1200$ & 30.4 & 35.7 & 975 & 80 & \\
\hline $12 / 1800$ & 30.5 & 35.6 & 971 & 85 & \multirow{7}{*}{ Category 2} \\
\hline $13 / 0000$ & 30.5 & 35.1 & 967 & 90 & \\
\hline $13 / 0600$ & 30.9 & 34.4 & 966 & 90 & \\
\hline $13 / 1200$ & 31.4 & 33.4 & 974 & 80 & \\
\hline $13 / 1800$ & 32 & 32.5 & 973 & 80 & \\
\hline $14 / 0000$ & 32.6 & 31.5 & 970 & 85 & \\
\hline $14 / 0600$ & 33.4 & 29.7 & 963 & 95 & \\
\hline $14 / 1200$ & 34.2 & 27.7 & 959 & 100 & \multirow{2}{*}{ Category 3} \\
\hline $14 / 1800$ & 35.3 & 25.2 & 959 & 100 & \\
\hline $15 / 0000$ & 36.4 & 22.6 & 959 & 95 & \multirow{3}{*}{ Category 2} \\
\hline $15 / 0600$ & 37.9 & 19.8 & 959 & 90 & \\
\hline $15 / 1200$ & 39.9 & 17 & 959 & 85 & \\
\hline $15 / 1800$ & 43.1 & 14.3 & 959 & 80 & \multirow{4}{*}{ Category 1} \\
\hline $16 / 0000$ & 47.6 & 13.4 & 958 & 75 & \\
\hline $16 / 0600$ & 50 & 12.1 & 957 & 70 & \\
\hline $16 / 1200$ & 52.3 & 10 & 959 & 65 & \\
\hline $16 / 1800$ & 55.3 & 8.3 & 969 & 60 & \multirow{5}{*}{$\begin{array}{c}\text { Extratropical } \\
\text { storm }\end{array}$} \\
\hline $17 / 0000$ & 57.3 & 6.1 & 977 & 50 & \\
\hline $17 / 0600$ & 58.7 & 2.9 & 987 & 45 & \\
\hline $17 / 1200$ & 59.3 & $1.5 \mathrm{E}$ & 994 & 40 & \\
\hline $17 / 1800$ & 60.1 & $5.3 \mathrm{E}$ & 997 & 40 & \\
\hline
\end{tabular}




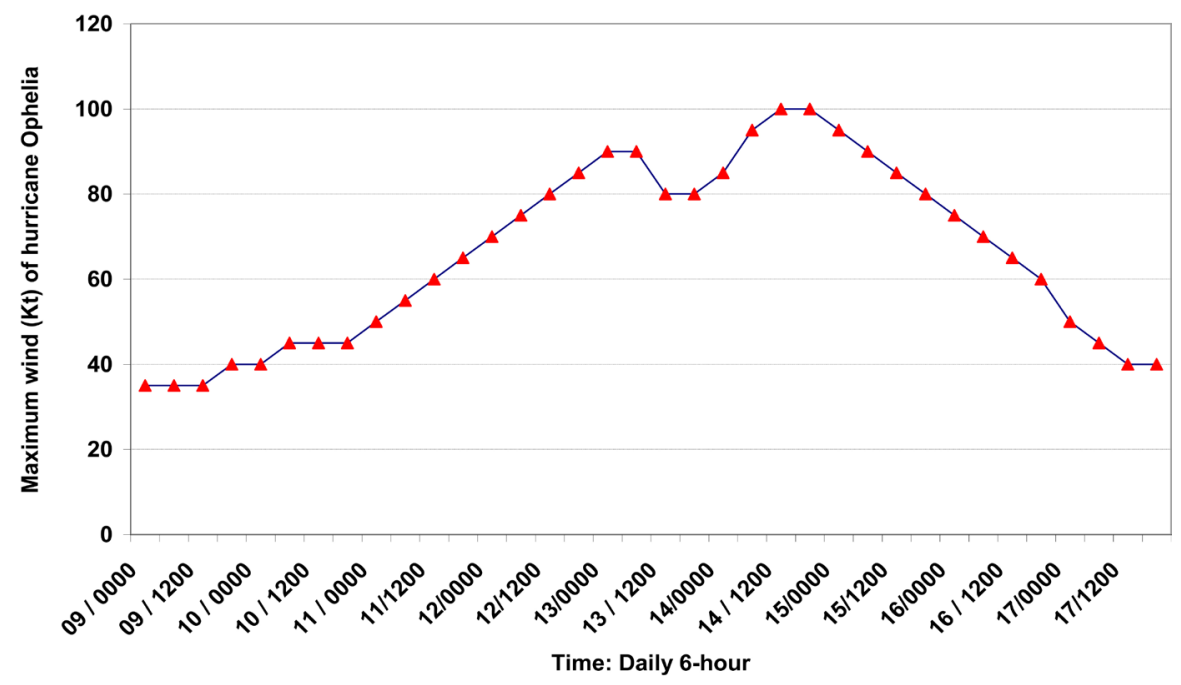

Figure 5. 6-hour maximum wind (Knot) at the center of hurricane Ophelia through the period (9-17 October 2017).

minimum value of pressure $957 \mathrm{hpa}$ at the center of hurricane Ophelia. Whereas, the lower pressure values became constant of $959 \mathrm{hpa}$.

\subsection{Study of the Anomaly of Geopotential Height at 500 hpa over North America and West of the Atlantic Ocean through the Period (9-17 October 2017)}

A 6 hour daily data of geopotential height at 500 hpa over north America and west of the Atlantic ocean through the period (9-17 October 2017) has been used to study the anomaly of geopotential height to catch the blocking episode and the blocking system. Analysis of this anomaly revealed that:-

1) Over the North America, it is found that there is a negative anomaly of geopotential height less than $(-100 \mathrm{~m})$ and arranged between $(-100 \mathrm{~m})$ to $(-225$ $\mathrm{m})$ over the $500 \mathrm{hpa}$ level through the period 09 October to 11 October 1200 UTC. Meanwhile, there is a positive anomaly more than $(+100 \mathrm{~m})$ from the day of 11 October 1800 UTC to the day of 16 October 0000 UTC. This positive anomaly arranged between $(+175 \mathrm{~m}$ and $+250 \mathrm{~m})$. After that period and to the end of the time interval of hurricane Ophelia there is a negative anomaly values arranged from $(-100 \mathrm{~m})$ to $(-150 \mathrm{~m})$.It is noticed that the days of 12 October and 14 October recorded the maximum positive anomaly $(+200 \mathrm{~m})$ through the whole period of hurricane Ophelia. As it is clear from the Table 2 and Figure 6.

2) Over the west of the Atlantic ocean, it has become clear that the period from 9 October to 11 October there is a positive anomaly of $(+100 \mathrm{~m})$ or more and arranged between $(+100 \mathrm{~m})$ and $(+250 \mathrm{~m})$. For all the period after that period there is a negative anomaly from $(-150 \mathrm{~m})$ to $(-300 \mathrm{~m})$. It is noticed that, the day 12 October to day 14 October recorded the maximum negative anomaly between $(-200 \mathrm{~m}$ and $-300 \mathrm{~m})$. The day of 12 October is the day of the highest negative anomaly with $(-300 \mathrm{~m})$ through the period of hurricane Ophelia. As shown in Table 2 and Figure 6. 
Table 2. The 6 hours anomaly of geopotential height at level 500 hpa over the North America and west of Atlantic Ocean during the period of hurricane Ophelia (9-17 October 2017).

\begin{tabular}{|c|c|c|}
\hline \multirow{2}{*}{ Date/Time (UTC) } & \multicolumn{2}{|c|}{ Anomaly of geopotential height at $500 \mathrm{hpa}$ level (m) } \\
\hline & Over north America & Over west of Atlantic Ocean \\
\hline 09/0000 & -200 & 200 \\
\hline $09 / 0600$ & -225 & 225 \\
\hline $09 / 1200$ & -175 & 225 \\
\hline $09 / 1800$ & -125 & 250 \\
\hline $10 / 0000$ & -150 & 250 \\
\hline $10 / 0600$ & -150 & 200 \\
\hline $10 / 1200$ & -150 & 200 \\
\hline $10 / 1800$ & -100 & 150 \\
\hline $11 / 0000$ & -100 & 200 \\
\hline $11 / 0600$ & -150 & 150 \\
\hline $11 / 1200$ & -200 & 100 \\
\hline $11 / 1800$ & 200 & 150 \\
\hline $12 / 0000$ & 200 & -300 \\
\hline $12 / 0600$ & 200 & -300 \\
\hline $12 / 1200$ & 200 & -300 \\
\hline $12 / 1800$ & 250 & -300 \\
\hline $13 / 0000$ & 200 & -200 \\
\hline $13 / 0600$ & 225 & -225 \\
\hline $13 / 1200$ & 250 & -200 \\
\hline $13 / 1800$ & 225 & -225 \\
\hline $14 / 0000$ & 200 & -200 \\
\hline $14 / 0600$ & 200 & -175 \\
\hline $14 / 1200$ & 200 & -175 \\
\hline $14 / 1800$ & 175 & -175 \\
\hline $15 / 0000$ & 200 & -150 \\
\hline $15 / 0600$ & 175 & -150 \\
\hline $15 / 1200$ & 200 & -150 \\
\hline $15 / 1800$ & 175 & -100 \\
\hline $16 / 0000$ & 175 & -100 \\
\hline $16 / 0600$ & -100 & -100 \\
\hline $16 / 1200$ & -100 & -100 \\
\hline $16 / 1800$ & -125 & -200 \\
\hline $17 / 0000$ & -150 & -200 \\
\hline $17 / 0600$ & -100 & -200 \\
\hline $17 / 1200$ & -150 & -200 \\
\hline $17 / 1800$ & -175 & -175 \\
\hline
\end{tabular}



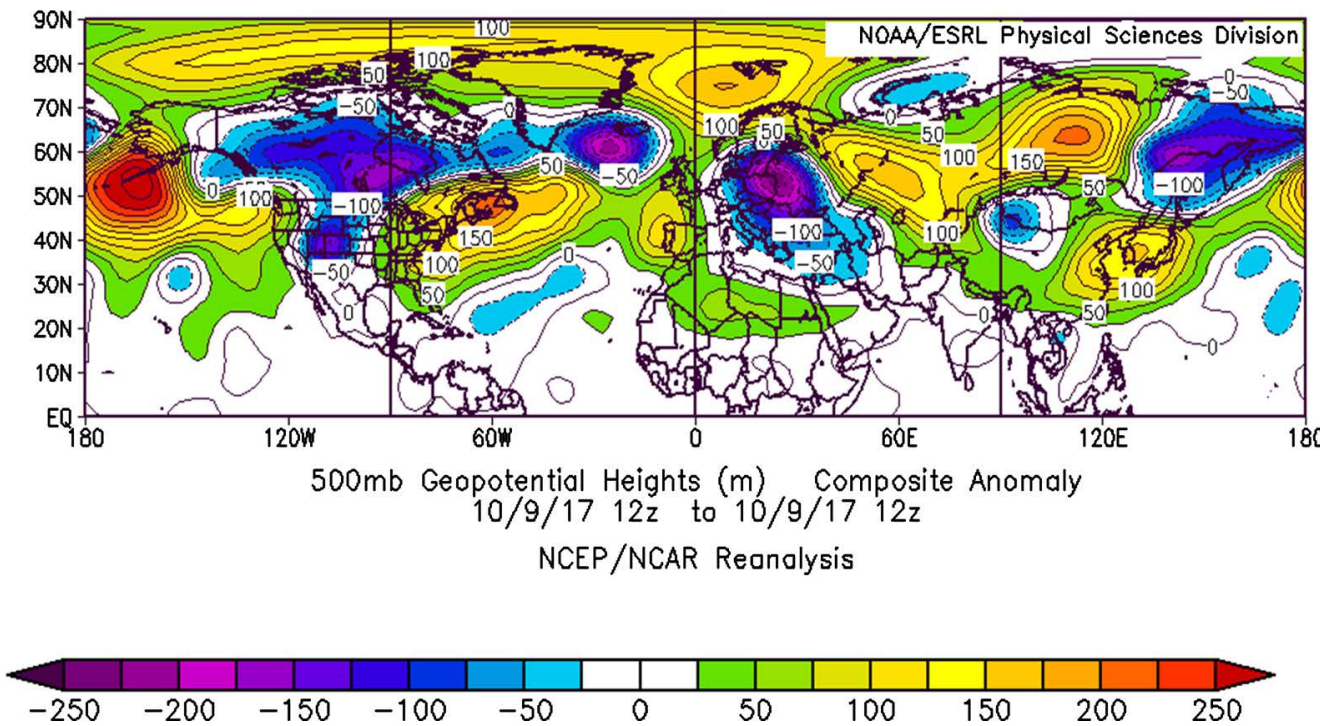

(a)

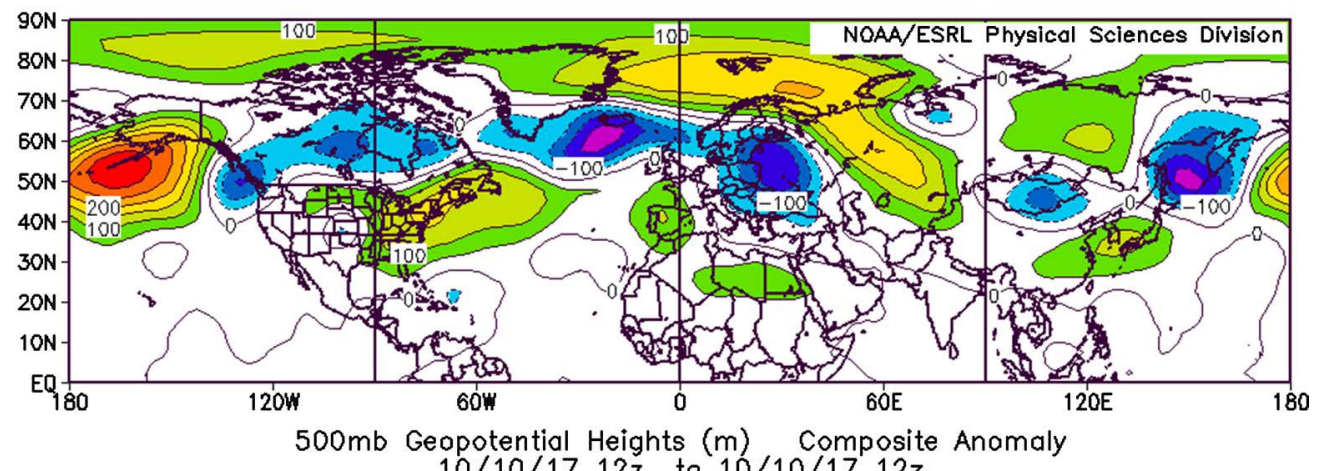
$10 / 10 / 1712 z$ to $10 / 10 / 1712 z$ NCEP/NCAR Reonalysis

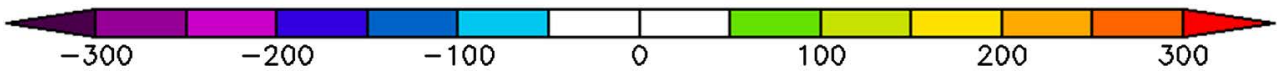

(b)

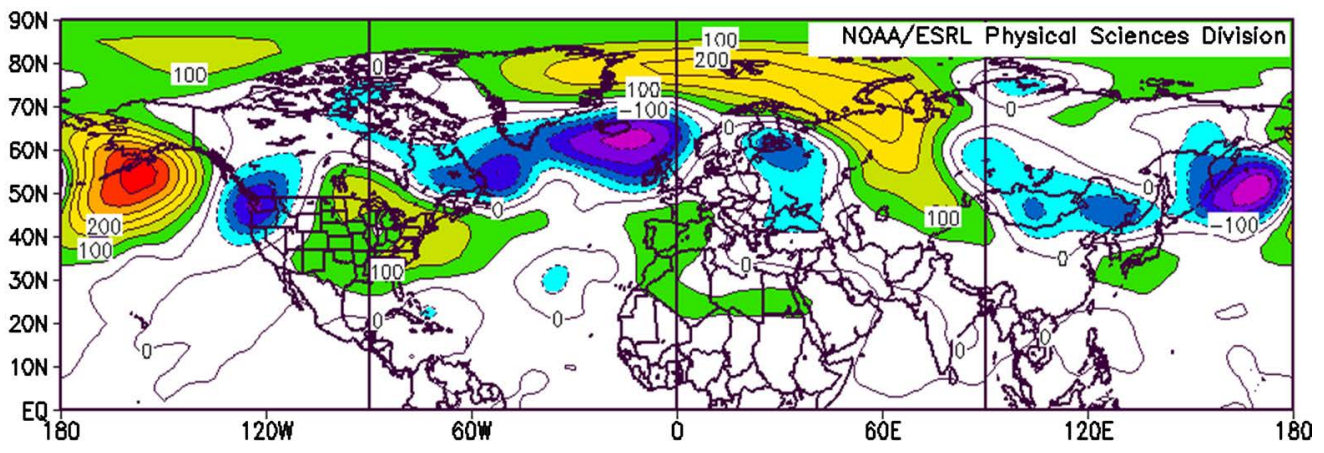

$500 \mathrm{mb}$ Geopotential Heights $(\mathrm{m})$ Composite Anomaly $10 / 11 / 1712 z$ to $10 / 11 / 1712 z$ NCEP/NCAR Reonalysis

\begin{tabular}{ll|l|l|l|l|l|l|l|l|l|l|}
\hline & & & & & & & & & \\
\hline-350 & -250 & -150 & -50 & 50 & 150 & 250 & 350
\end{tabular}

(c) 


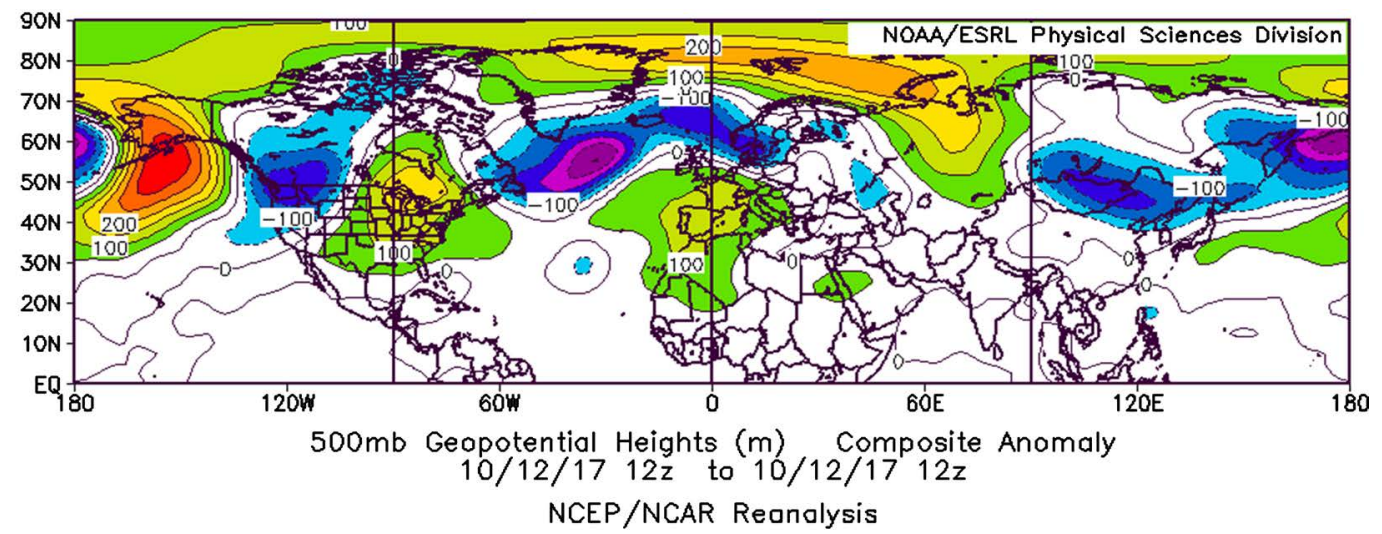

\begin{tabular}{l|c|c|c|c|c|c|c|c|c|}
\hline & & & & & & & & & $\frac{1}{300}$ \\
\hline-300 & -200 & -100 & 0 & 100 & 200 & 300
\end{tabular}

(d)

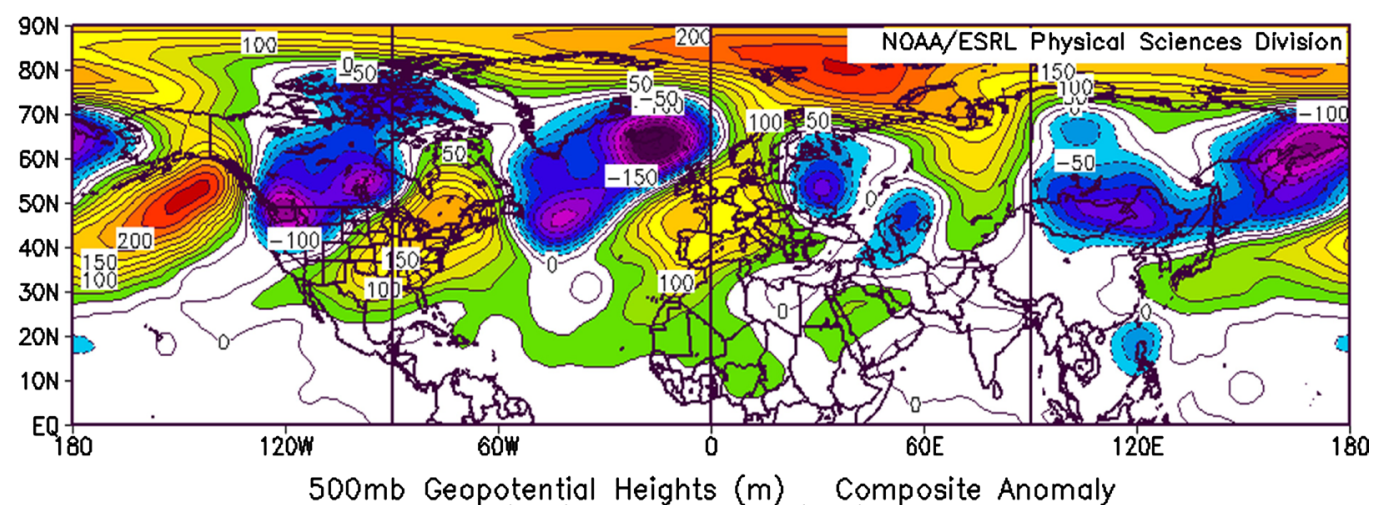
$10 / 13 / 1712 z$ to $10 / 13 / 1712 z$ NCEP/NCAR Reonalysis

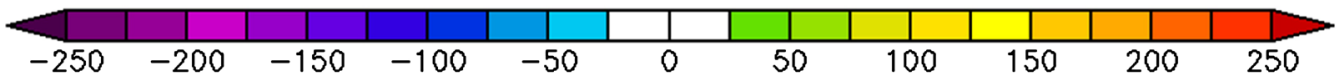

(e)

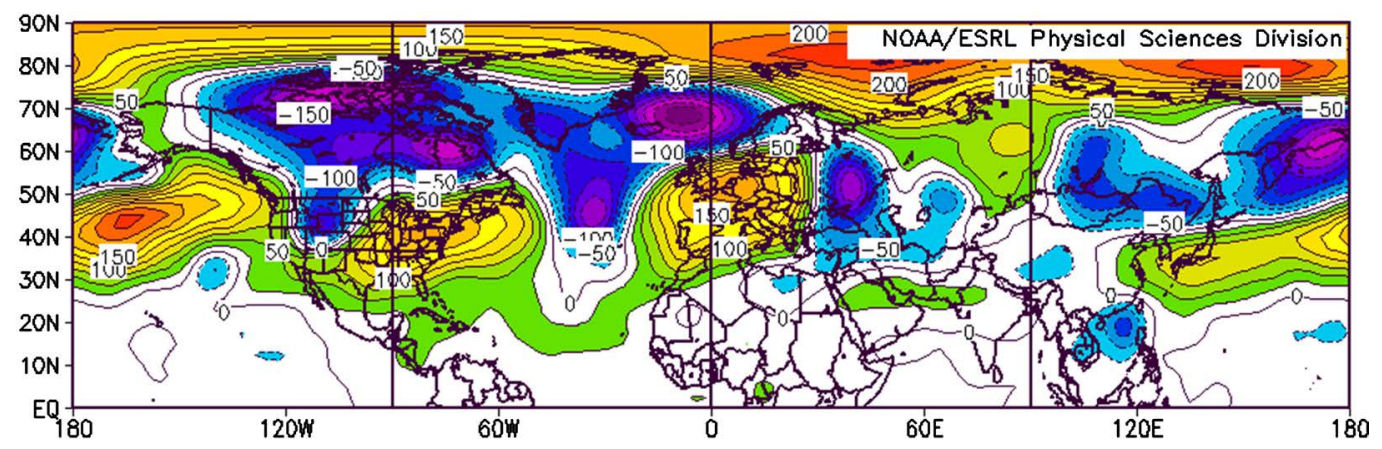

$500 \mathrm{mb}$ Geopotential Heights ( $\mathrm{m}$ ) Composite Anamaly $10 / 14 / 1712 z$ to $10 / 14 / 1712 z$ NCEP/NCAR Reanalysis

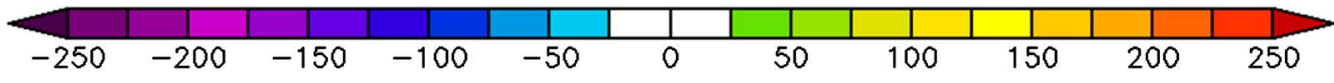

(f) 

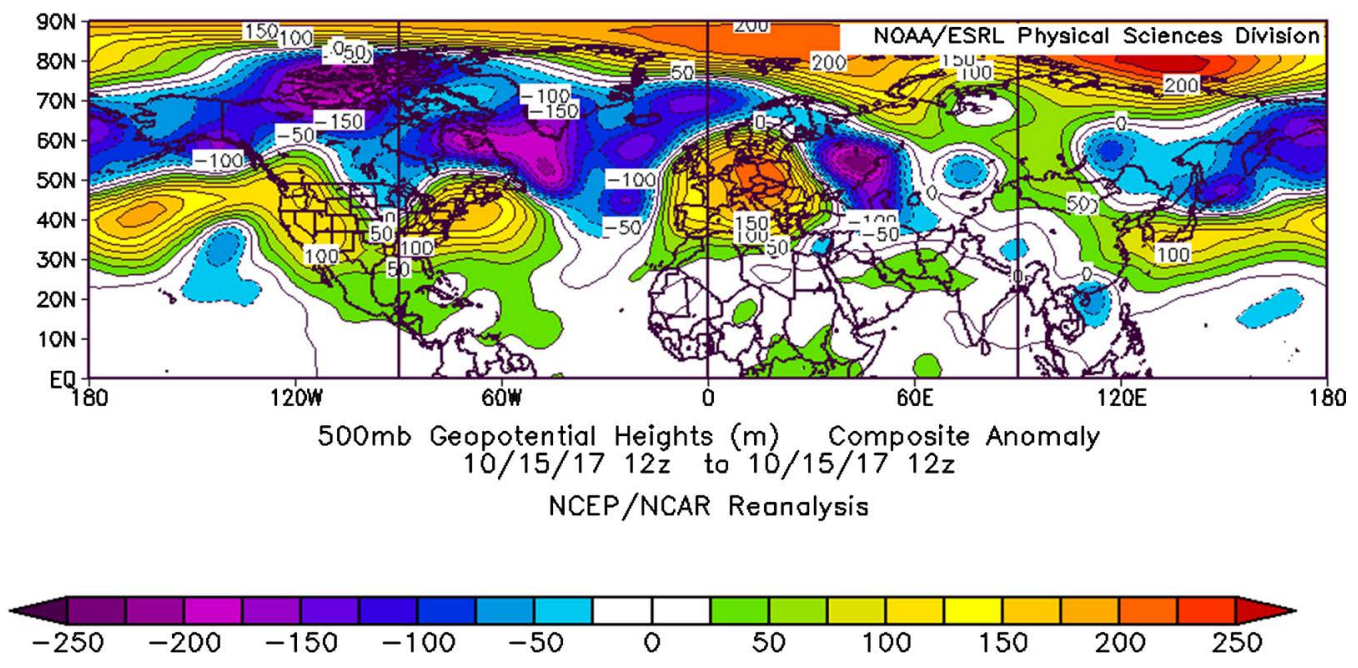

(g)

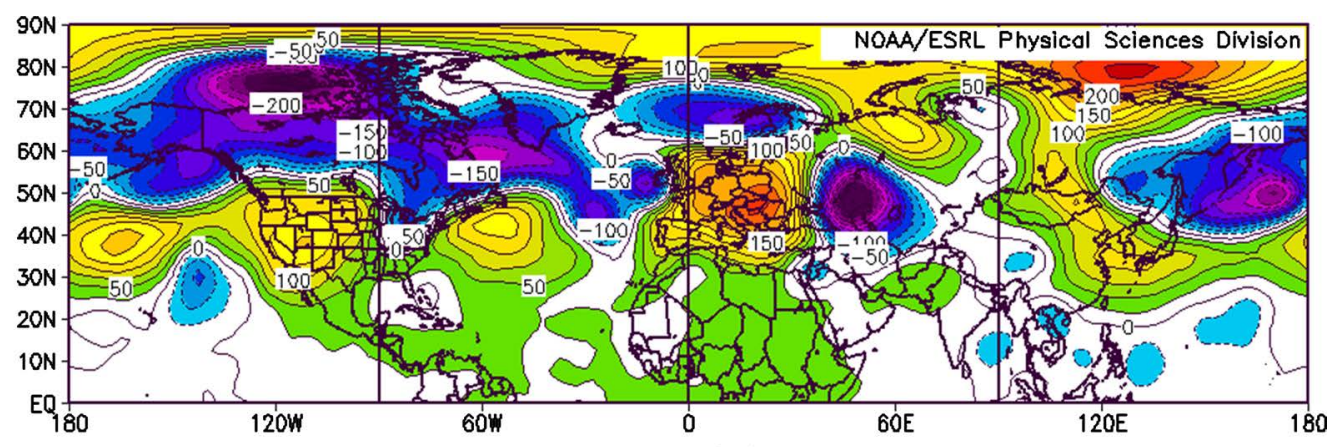

$500 \mathrm{mb}$ Geopotential Heights ( $\mathrm{m}$ ) Composite Anamaly

$10 / 16 / 1712 z$ to $10 / 16 / 1712 z$

NCEP/NCAR Reanalysis

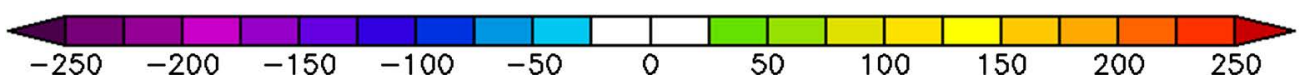

(h)

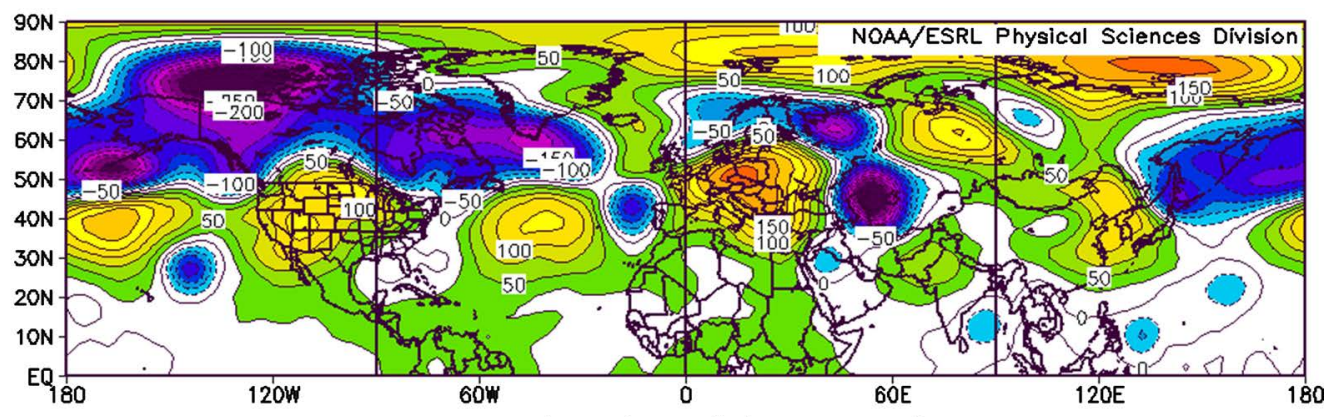

$500 \mathrm{mb}$ Geopotential Heights (m) Composite Anomaly

$10 / 17 / 1712 z$ to $10 / 17 / 1712 z$

NCEP/NCAR Reanalysis

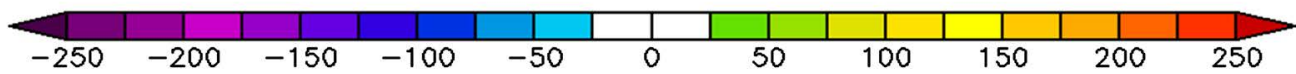

(i)

Figure 6. Daily composite anomaly of 500 hpa geopotential height at 1200 UTC for the period of hurricane Ophelia (9-17 October 2017). 
3) Figure 7 shows that the anomaly of 6-hour geopotential height (m) at 500 hpa level over north America varies contradicted to its values over the west Atlantic ocean through the period of hurricane Ophelia (9-17 October 2017).

\subsection{Study of the Anomaly of Meridional Wind Component at 500 hpa over West and East of Atlantic Ocean through the Period (9-17 October 2017)}

A 6 hour daily data of the meridional wind component at $500 \mathrm{hpa}$ over the west and east of the Atlantic ocean through the period (9-17 October 2017) has been used to study the anomaly of the meridional wind component. Analysis of this anomaly revealed that:

1) Over the west Atlantic ocean, it is clear that the meridional wind is a southerly wind with anomaly reached $(-17.5 \mathrm{~m} / \mathrm{s})$ for the period from 09 October 0000 UTC to 10 October 0600 UTC. From 11 October 0000 UTC to the day of 16 October 0600 UTC, there are negative anomaly of meridional wind component and the wind is southerly wind. The maximum negative anomaly is reached to $(-30 \mathrm{~m} / \mathrm{s})$ on the end of the day of 16 October and stay for the day of 0000 UTC. The meridional wind becomes northward from the day of 16 October 1200 UTC until the dissipation of hurricane Ophelia on 17 October. Table 3 and Figure 8 illustrates the variations of meridional wind components over the west Atlantic Ocean.

2) Over the east Atlantic Ocean, it found that, the meridional wind is a northerly wind from the day of 9 October to the start of the day of 11 October. The northerly wind anomaly reached to $(+15 \mathrm{~m} / \mathrm{s})$ through that period. From the night of the day 11 October until the mid of the day of 17 October, the meridional wind is completely north wind over the east part of the Atlantic Ocean. It

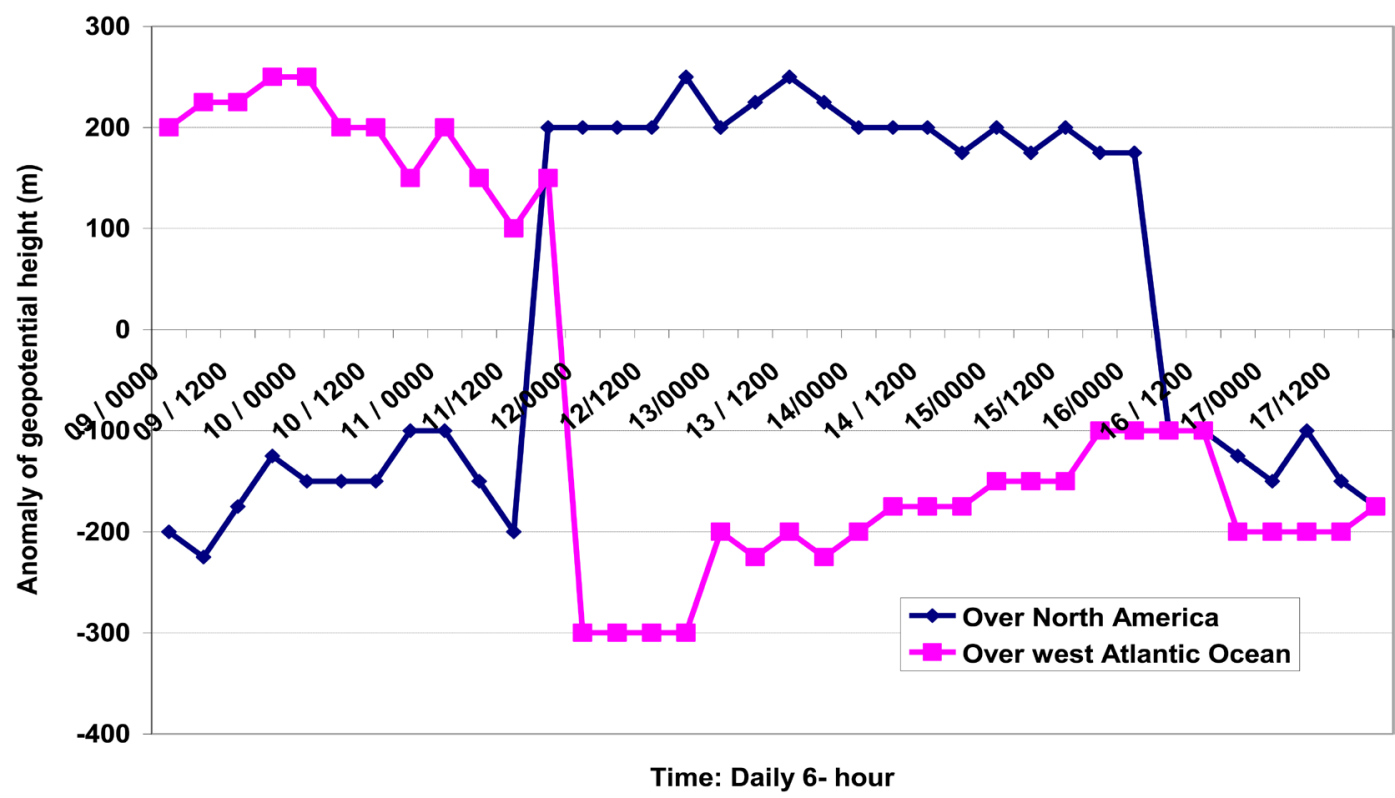

Figure 7. 6-hour anomaly of geopotential height (m) at 500 hpa level over north America and west Atlantic ocean through the period of hurricane Ophelia (9-17 October 2017). 
Table 3. The 6 hours anomaly of meridional wind component at level 500 hpa over the west and east Atlantic Ocean during the period of hurricane Ophelia (9-17 October 2017).

\begin{tabular}{|c|c|c|}
\hline \multirow{2}{*}{ Date/Time (UTC) } & \multicolumn{2}{|c|}{ Anomaly of meridional wind component $(\mathrm{m} / \mathrm{s})$ at $500 \mathrm{hpa}$ leve } \\
\hline & Over west Atlantic Ocean & Over east Atlantic Ocean \\
\hline 09/0000 & -15 & 15 \\
\hline $09 / 0600$ & -17.5 & 15 \\
\hline $09 / 1200$ & -17.5 & 12.5 \\
\hline $09 / 1800$ & -15 & 15 \\
\hline $10 / 0000$ & -15 & 10 \\
\hline $10 / 0600$ & -12.5 & 15 \\
\hline $10 / 1200$ & 0 & 10 \\
\hline $10 / 1800$ & 0 & 10 \\
\hline $11 / 0000$ & -10 & 10 \\
\hline $11 / 0600$ & -10 & -10 \\
\hline $11 / 1200$ & -15 & 0 \\
\hline $11 / 1800$ & -10 & 15 \\
\hline $12 / 0000$ & -10 & 15 \\
\hline $12 / 0600$ & -10 & 10 \\
\hline $12 / 1200$ & -10 & 10 \\
\hline $12 / 1800$ & -10 & 15 \\
\hline $13 / 0000$ & -10 & 15 \\
\hline $13 / 0600$ & -15 & 20 \\
\hline $13 / 1200$ & -20 & 20 \\
\hline $13 / 1800$ & -25 & 20 \\
\hline $14 / 0000$ & -25 & 25 \\
\hline $14 / 0600$ & -25 & 25 \\
\hline $14 / 1200$ & -22.5 & 22.5 \\
\hline $14 / 1800$ & -25 & 25 \\
\hline $15 / 0000$ & -15 & 25 \\
\hline $15 / 0600$ & -15 & 25 \\
\hline $15 / 1200$ & -25 & 25 \\
\hline $15 / 1800$ & -30 & 30 \\
\hline $16 / 0000$ & -30 & 20 \\
\hline $16 / 0600$ & -25 & 25 \\
\hline $16 / 1200$ & 15 & 20 \\
\hline $16 / 1800$ & 10 & 20 \\
\hline $17 / 0000$ & 15 & 25 \\
\hline $17 / 0600$ & 20 & 25 \\
\hline $17 / 1200$ & 20 & -25 \\
\hline $17 / 1800$ & 20 & -30 \\
\hline
\end{tabular}




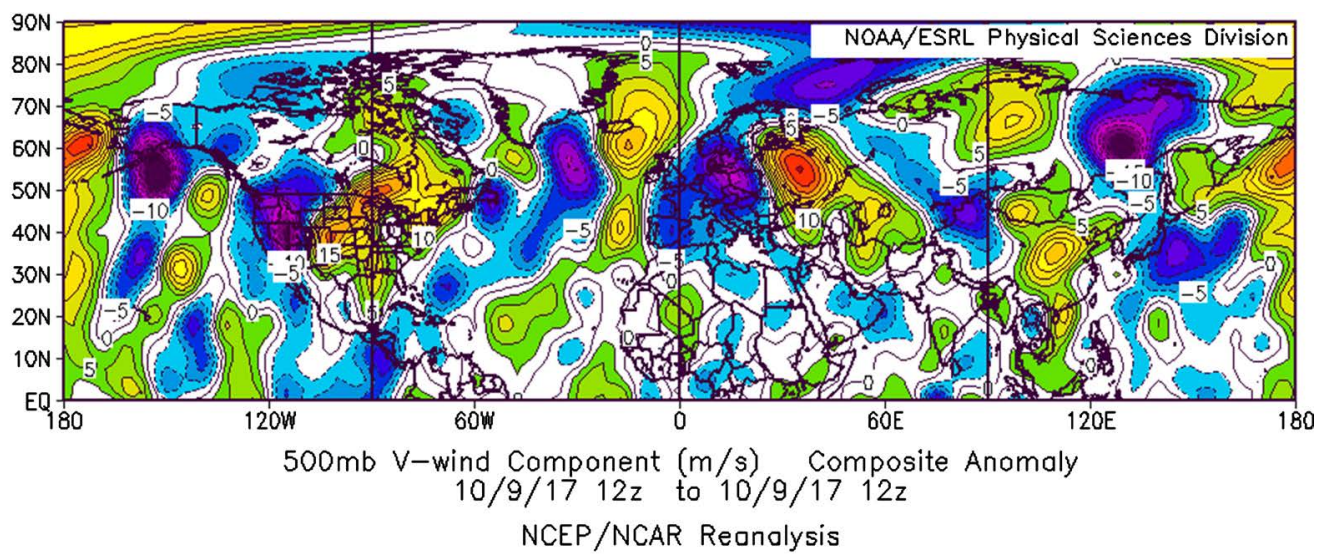

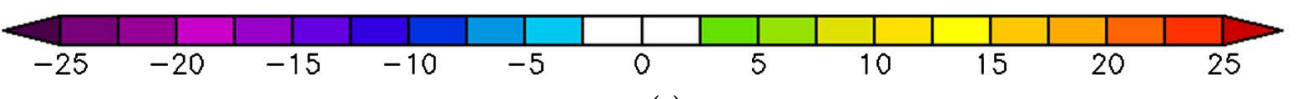

(a)

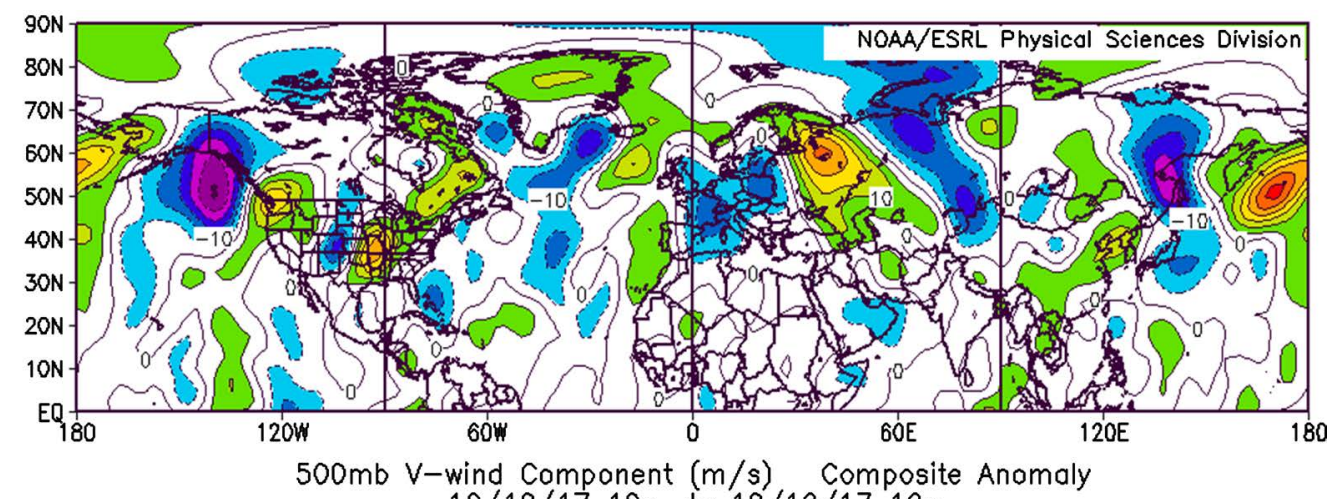
$10 / 10 / 1712 z$ to $10 / 10 / 1712 z$ NCEP/NCAR Reanalysis

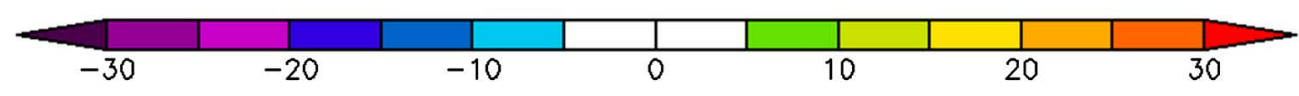

(b)

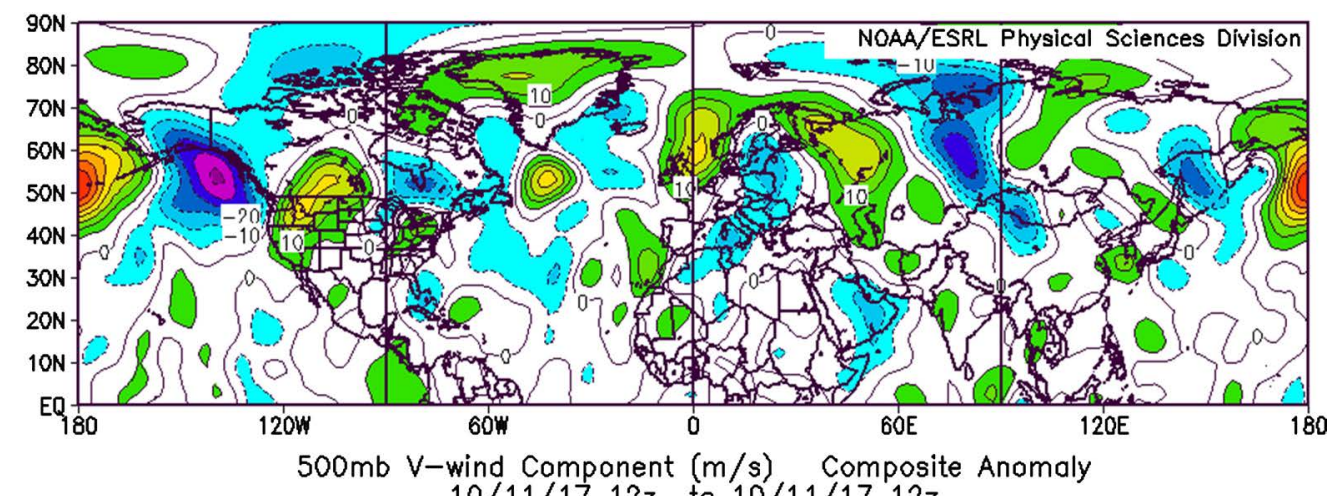
$10 / 11 / 1712 z$ to $10 / 11 / 1712 z$ NCEP/NCAR Reanalysis

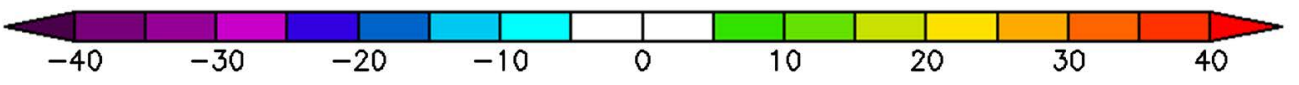

(c) 

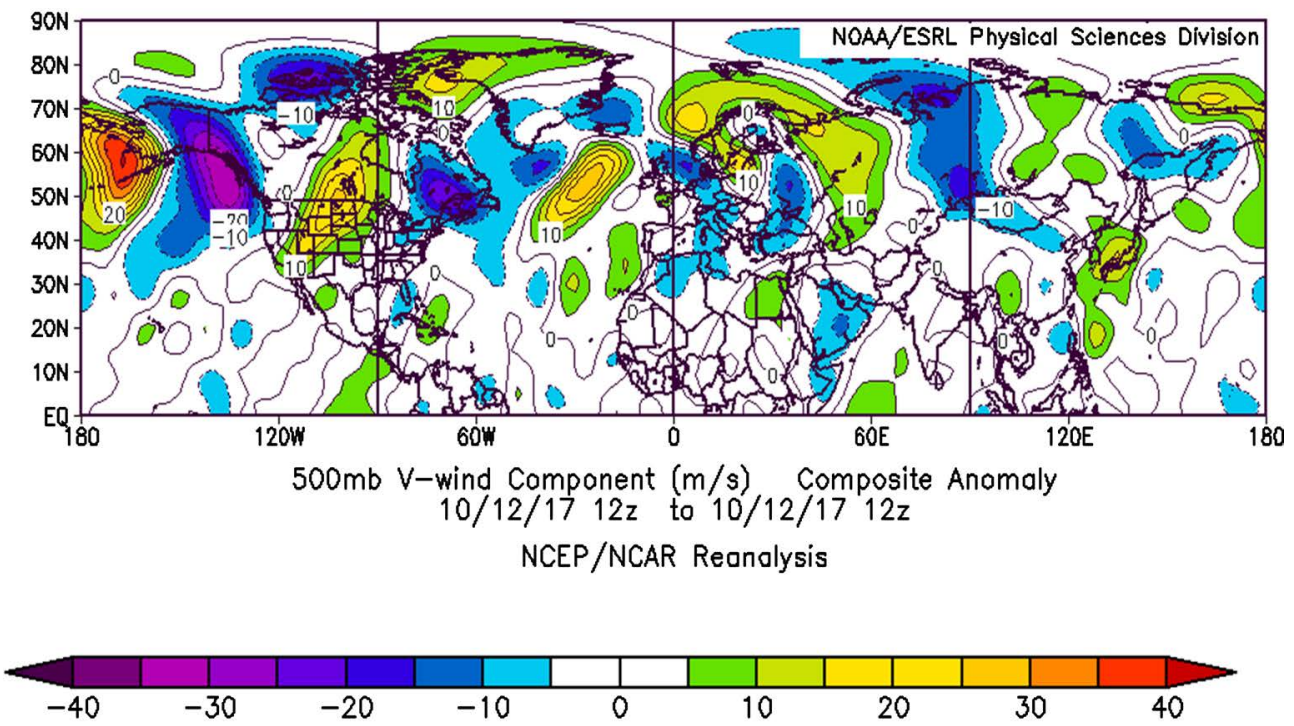

(d)
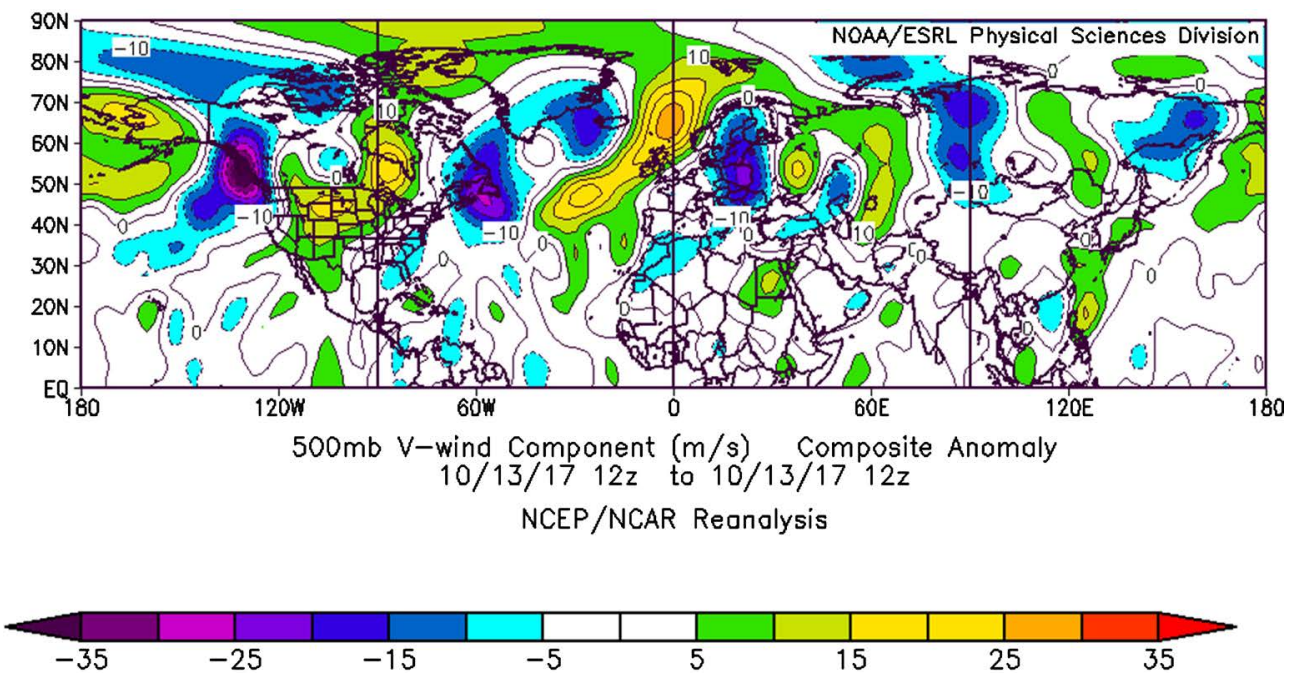

(e)

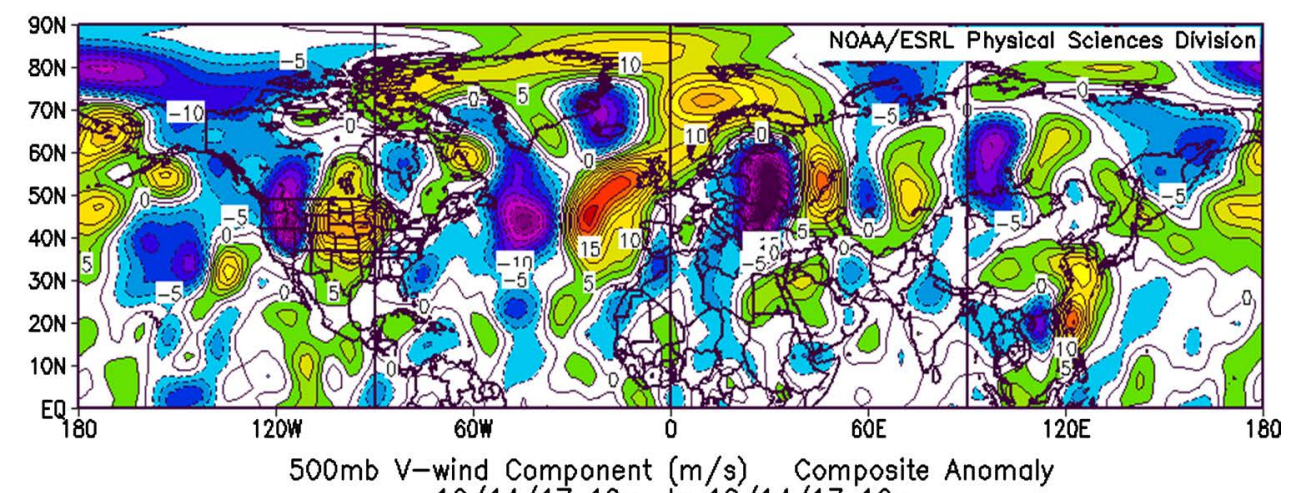

$10 / 14 / 1712 z$ to $10 / 14 / 1712 z$ NCEP/NCAR Reonalysis

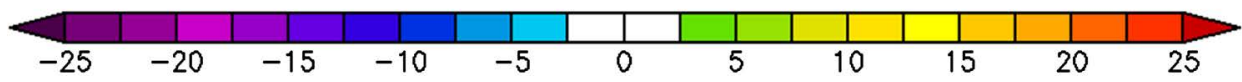

(f) 

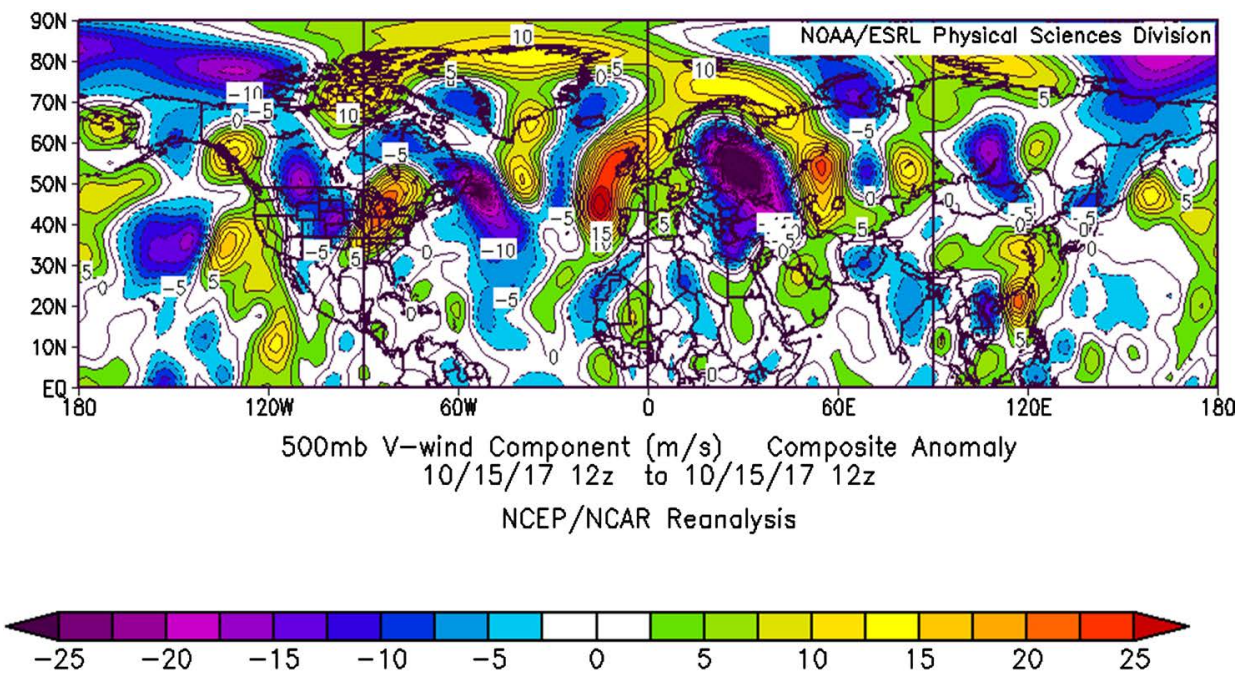

(g)
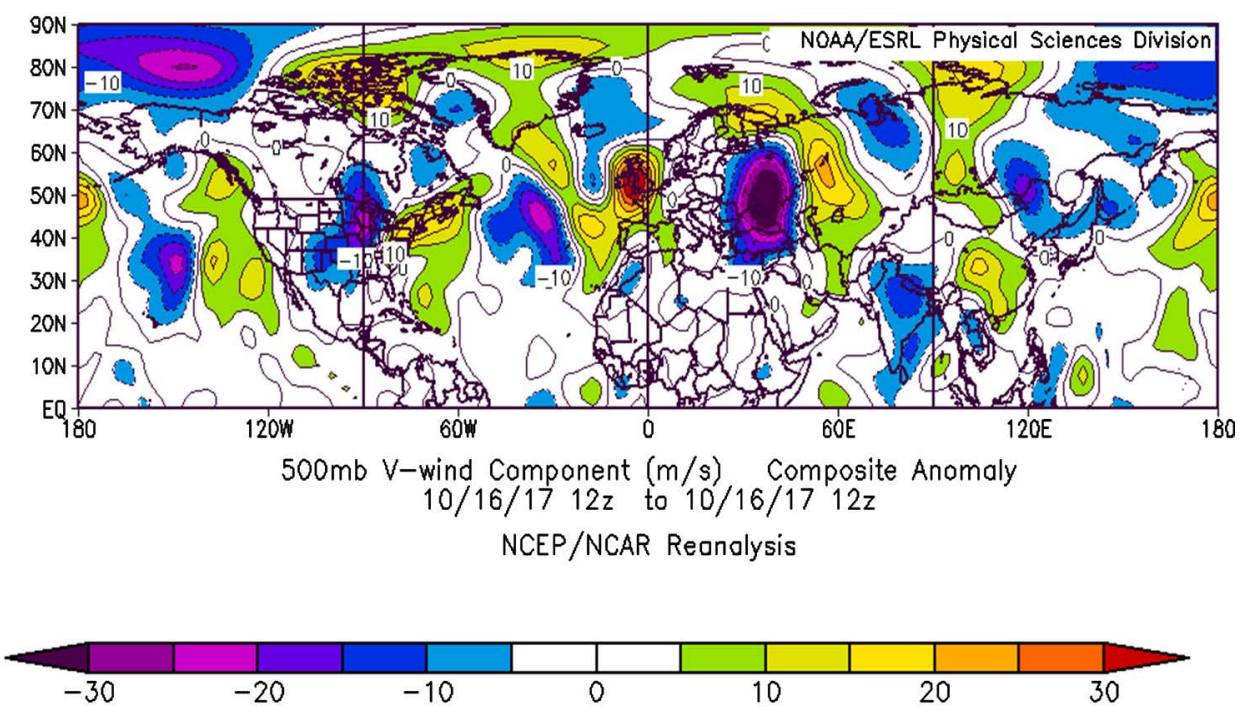

(h)
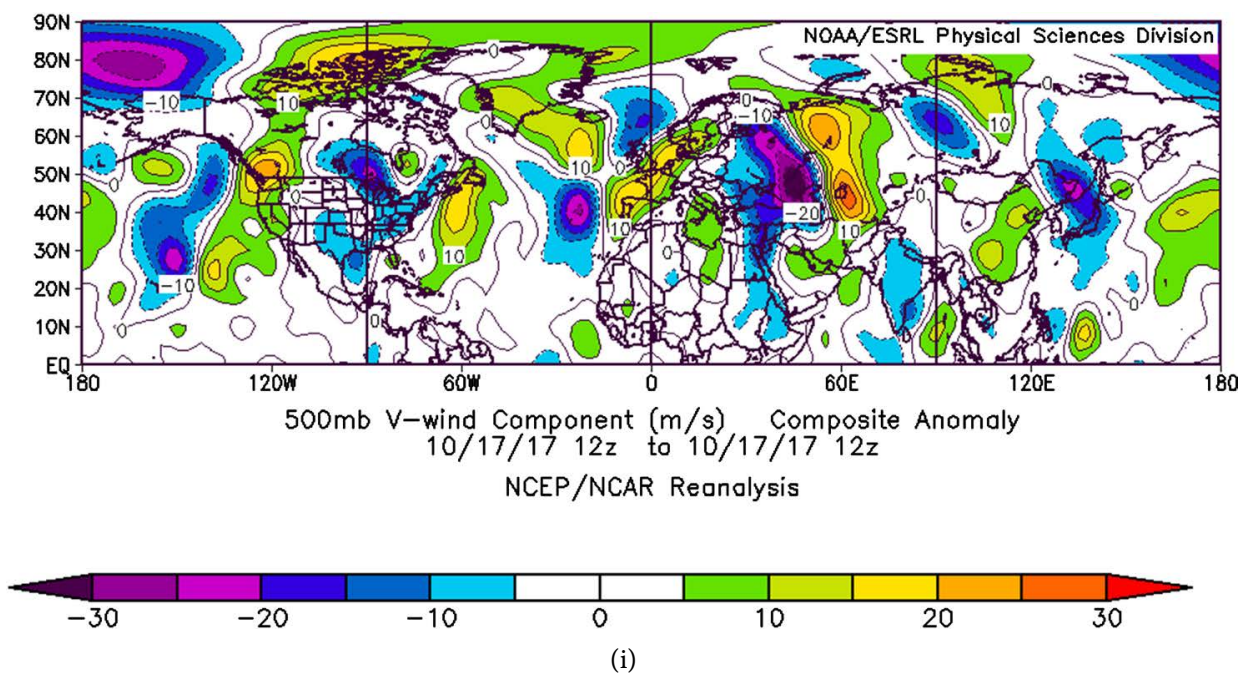

Figure 8. Daily composite anomaly of $500 \mathrm{hpa}$ meridional wind component (m/s) at 1200 UTC for the period of hurricane Ophelia (9-17 October 2017). 
reaches its maximum positive anomaly of $(+30 \mathrm{~m} / \mathrm{s})$ on the day of 15 October. For the two days 14 and 15 October, the meridional wind anomaly is a higher value between $25 \mathrm{~m} / \mathrm{s}$ and $30 \mathrm{~m} / \mathrm{s}$. Table 3 and Figure 8 illustrates the variations of meridional wind components over the west Atlantic Ocean.

3) Figure 9 illustrates that the variability of 6-hour anomaly of meridional wind component at $500 \mathrm{hpa}$ level over the west Atlantic ocean is contradicting to the east Atlantic ocean through the period of hurricane Ophelia (9-17 October 2017).

\subsection{The Teleconnection between the Development of Hurricane Ophelia and the Blocking System over North America}

To study the teleconnection between the development of hurricane Ophelia and the blocking system over North America linear correlation coefficient technique used. The maximum wind speed and the surface pressure at the center of hurricane Ophelia has been correlation test with the blocking system persist over north America and Atlantic ocean through the period (9-17 October) of the year 2017. The results revealed that:-

1) There is a strong positive correlation coefficient of (0.890) between the surface pressure at the center of hurricane Ophelia and the geopotential height anomaly at $500 \mathrm{hpa}$ level over the west Atlantic Ocean as shown in Table 4.

2) There is an outstanding negative correlation coefficient of $(-0.859)$ between the maximum wind speed for the hurricane Ophelia and the pressure at the center of Ophelia. As illustrated in Table 4.

3) There is a significant positive correlation coefficient of (0.703) between the maximum wind speed for the hurricane Ophelia and geopotential height anomaly at $500 \mathrm{hpa}$ level over the west Atlantic Ocean. As clear from Table 4.

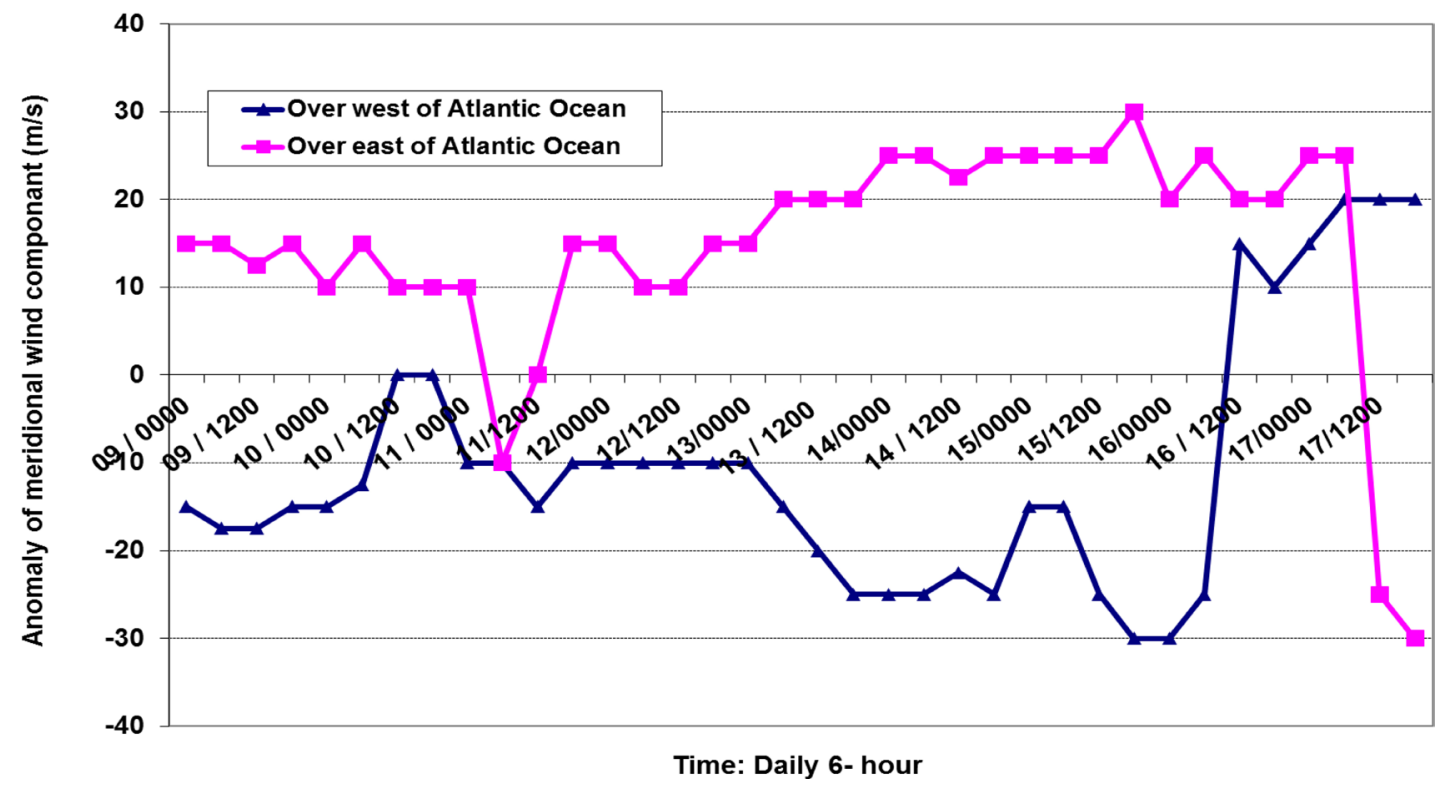

Figure 9. 6-hour anomaly of meridional wind component $(\mathrm{m} / \mathrm{s})$ at $500 \mathrm{hpa}$ level over west and east Atlantic ocean through the period of hurricane Ophelia (9-17 October 2017). 
Table 4. The correlation coefficient matrix of the hurricane Ophelia parameters and meteorological parameters over North America and North Atlantic Ocean through the period (9-17 October 2017).

\begin{tabular}{|c|c|c|c|c|c|c|}
\hline $\begin{array}{l}\text { Correlation coefficient } \\
\text { and } \\
\text { Meteorological parameters }\end{array}$ & $\begin{array}{l}\text { Maximum } \\
\text { wind of } \\
\text { Ophelia }\end{array}$ & $\begin{array}{c}\text { pressure at } \\
\text { the center of } \\
\text { Ophelia }\end{array}$ & $\begin{array}{c}\text { Geopotential } \\
\text { height anomaly at } \\
500 \mathrm{hpa} \text { level over } \\
\text { north America }\end{array}$ & $\begin{array}{c}\text { Geopotential } \\
\text { height anomaly at } \\
500 \text { hpa level over } \\
\text { west Atlantic } \\
\text { Ocean }\end{array}$ & $\begin{array}{l}\text { Meridional wind } \\
\text { component at } \\
500 \text { hpa level } \\
\text { over west } \\
\text { Atlantic Ocean }\end{array}$ & $\begin{array}{c}\text { Meridional wind } \\
\text { component at } 500 \\
\text { hpa level over east } \\
\text { Atlantic Ocean }\end{array}$ \\
\hline Maximum wind of Ophelia & 1 & $-0.859^{*}$ & -0.680 & $0.703^{* *}$ & 0.307 & -0.575 \\
\hline $\begin{array}{c}\text { pressure at the center of } \\
\text { Ophelia }\end{array}$ & $-0.859^{*}$ & 1 & $0.890^{*}$ & -0.673 & -0.503 & 0.505 \\
\hline $\begin{array}{c}\text { Geopotential height anomaly } \\
\text { at } 500 \mathrm{hpa} \text { level over north } \\
\text { America }\end{array}$ & -0.680 & $0.890^{*}$ & 1 & -0.658 & -0.498 & 0.455 \\
\hline $\begin{array}{c}\text { Geopotential height anomaly } \\
\text { at } 500 \mathrm{hpa} \text { level over west } \\
\text { Atlantic Ocean }\end{array}$ & $0.703^{* *}$ & -0.673 & -0.658 & 1 & -0.088 & -0.170 \\
\hline $\begin{array}{c}\text { Meridional wind component } \\
\text { at } 500 \mathrm{hpa} \text { level over west } \\
\text { Atlantic Ocean }\end{array}$ & 0.307 & -0.503 & -0.498 & -0.088 & 1 & -0.496 \\
\hline $\begin{array}{c}\text { Meridional wind component } \\
\text { at } 500 \mathrm{hpa} \text { level over east } \\
\text { Atlantic Ocean }\end{array}$ & -0.575 & 0.504 & 0.455 & -0.170 & -0.496 & 1 \\
\hline
\end{tabular}

*: with significant level > 99\%; $*$ : with significant level $>95 \%$.

The present work using the NCEP/NCAR 6 hour reanalysis data of meteorological parameters geopotential height and meridional wind component at 500 hpa level for the northern hemisphere to study the unique hurricane Ophelia. Hurricane Ophelia has an unusual position of formation and extremely track over the North Atlantic Ocean through the period (9 -17) October 2017. Its development stages and its dissipation have been analyzed. The anomaly of geopotential height and meridional wind component at level of $500 \mathrm{hpa}$ studied through the period of hurricane Ophelia. Moreover, the meteorological parameters of surface pressure and maximum wind of hurricane Ophelia analyzed. The criteria of existence of blocking episode examined through the period of hurricane Ophelia. From the results, it has become clear that the distribution of positive anomaly and negative anomaly of geopotential height at 500 hpa level over the north America and north Atlantic region control the development, strength and the track of hurricane Ophelia toward the northward. In addition to that, there are strong direct relationships between the existing, strength and track of Ophelia and the persistence of blocking high over the northern America through the period of study. One can conclude that the persistence of a huge blocking high episode over the North America creates a deep of the low pressure system over the north west of the Atlantic Ocean. This dipole of a pressure system causes the development and control the strength and track of hurricane Ophelia. This unique distribution of the pressure system over North America and north of Atlantic Ocean leads to a low pressure system appears over north Atlantic in- 
stead of its normal distribution of the Azores high. In addition to that, the blocking pressure system steer the wind component of the hurricane Ophelia to be mainly meridional wind and catch this hurricane toward to the northward to landfall over Ireland.

\section{Acknowledgements}

The authors hope to thank the NOAA/ESRL Physical Sciences Division. Image provided by the NOAA/ESRL Physical Sciences Division, Boulder Colorado from their Web site at http://www.esrl.noaa.gov/psd/. Also, thanks to the national hurricane center for tropical cyclone report (AL172017) of hurricane Ophelia.

\section{Conflicts of Interest}

The authors declare no conflicts of interest regarding the publication of this paper.

\section{References}

Brunner, L. \& Steiner, A. K. (2017). A Global Perspective on Atmospheric Blocking Using GPS Radio Occultation-One Decade of Observations. Atmospheric Measurement Techniques, 10, 4727-4745. https://doi.org/10.5194/amt-10-4727-2017

Dole, R. M. (1982). Persistent Anomalies of the Extratropical Northern Hemisphere Wintertime Circulation. Ph.D. Thesis, Cambridge, MA: Massachusetts Institute of Technology.

Dole, R. M. (1986). The Life Cycles of Persistent Anomalies and Blocking over the North Pacific. Advances in Geophysics, 29, 31-70. https://doi.org/10.1016/S0065-2687(08)60034-5

Dole, R. M., \& Gordon, N. D. (1983). Persistent Anomalies of the Extra-Tropical Northern Hemisphere Wintertime Circulation: Geographical Distribution and Regional Persistence Characteristics. Monthly Weather Review, 111, 1567-1586. https://doi.org/10.1175/1520-0493(1983)111<1567:PAOTEN>2.0.CO;2

Hafez, Y. Y. (2008). The Role Played by Blocking over the Northern Hemisphere on Hurricane Katrina. The Journal of American Science, 4, 10-25.

Hafez, Y. Y. (2011). Relationship between Geopotential Height Anomalies over North America and Europe and the USA Landfall Atlantic Hurricanes Activity. Journal of American Science, 7, 663-671.

Hafez, Y. Y. (2012). Book Chapter; Blocking Systems Persist over North Hemisphere and Its Role in Extreme Hot Waves over Russia during Summer 2010. In I. Yucel (Ed.), Atmospheric Model Applications, InTech. https://doi.org/10.5772/33810

Hafez, Y. Y., \& Almazroui, M. (2013). The Role Played by Blocking Systems over Europe in Abnormal Weather over Kingdom of Saudi Arabia in Summer 2010. Advances in Meteorology, 2013, Article ID: 705406, 20 p.

Hafez, Y. Y., \& Almazroui, M. (2016). Study of the Relationship between Geopotential Height Anomaly over Europe and Extreme Abnormal Weather over the Eastern Mediterranean and Middle East during December 2013. Arabian Journal of Geosciences, 9, 1-13. https://doi.org/10.1007/s12517-016-2424-8

Kalnay, E., Kanamitsu, M., Kistler, R. et al. (1996). The NCEP/NCAR 40-Year Reanalysis 
Project. Bulletin of the American Meteorological Society, 77, 437-470. https://doi.org/10.1175/1520-0477(1996)077<0437:TNYRP>2.0.CO;2

Kendall, M. G., \& Stuart, A. (1973). The Advanced Theory of Statistics, Volume 2: Inference and Relationship. London: Charles Griffin.

Mattingly, K., McLead, J. T., Knox, J. A., Shepherd, M., \& Mote, T. (2014). A Climatological Assessment of Greenland Blocking Conditions Associated with the Track of Hurricane Sandy and Historical North Atlantic Hurricanes: GREENLAND BLOCKING AND NORTH ATLANTIC HURRICANES. International Journal of Climatology, 35, 746-760. https://doi.org/10.1002/joc.4018

Mctaggart-Cowanr, R., Bosart, L. F., Davis, C. A., Atallah, E. H., Gyakum, J. R., \& Emanuel, K. A. (2006). Analysis of Hurricane Catarina (2004). Monthly Weather Review, 134, 3029-3053. https://doi.org/10.1175/MWR3330.1

Moore, P. (2018). An Analysis of Storm Ophelia, Which Struck Ireland on 16th October 2017. Dublin: Met Éireann Glasnevin Hill.

Namias, J. (1964). Seasonal Persistence and Recurrence of European Blocking during 1958-60. Tellus, 29, 394-407.

Park, Y. J., \& Ahn, J. B. (2014). Characteristics of Atmospheric Circulation over East Asia Associated with Summer Blocking. Journal of Geophysical Research, Atmospheres, 119, 726-738. https://doi.org/10.1002/2013JD020688

Pezza, A. B., \& Simmonds, I. (2006). Catarina: The First South Atlantic Hurricane and Its Association with Vertical Wind Shear and High Latitude Blocking (pp. 353-364). Victoria: The University of Melbourne.

Renwick, J. A. (2005). Persistent Positive Anomalies in the Southern Hemisphere Circulation. Monthly Weather Review, 133, 977-988. https://doi.org/10.1175/MWR2900.1

Rex, D. F. (1950a). Blocking Action in the Middle Troposphere and Its Effect on Regional Climate I: An Aerological Study of Blocking Action. Tellus, 3, 196-211. https://doi.org/10.3402/tellusa.v2i3.8546

Rex, D. F. (1950b). Blocking Action in the Middle Troposphere and Its Effect on Regional Climate II: The Climatology of Blocking Action. Tellus, 3, 275-301.

Rex, D. F. (1951). The Effect of Atlantic Blocking Action upon European Climate. Tellus, 3, 100-112. https://doi.org/10.3402/tellusa.v3i2.8617

Sinclair, M. R. (1996). A Climatology of Anticyclones and Blocking for the Southern Hemisphere. Monthly Weather Review, 124, 245-263. https://doi.org/10.1175/1520-0493(1996)124<0245:ACOAAB >2.0.CO;2

Stewart, S. R. (2018). National Hurricane Center, Tropical Cyclone Report, Hurricane Ophelia, (AL172017).

Treidl, R. A., Birch, E. C., \& Sajecki, P. (1981). Blocking Action in the Northern Hemisphere: A Climatological Study. Atmosphere-Ocean, 19, 1-23. https://doi.org/10.1080/07055900.1981.9649096

Whan, K., Zwiers, F., \& Sillmann, J. (2016). The Influence of Atmospheric Blocking on Extreme Winter Minimum Temperatures in North America. Journal of Climate, 29, 4361-4381. https://doi.org/10.1175/JCLI-D-15-0493.1

Wiedenmann, J. M., Lupo, A. R., Mokhov, I. I., \& Tikhonova, E. A. (2002). The Climatology of Blocking Anticyclones for the Northernand Southern Hemispheres: Block Intensity as a Diagnostic. Journal of Climate, 15, 3459-3473. https://doi.org/10.1175/1520-0442(2002)015<3459:TCOBAF $>2.0 . C O ; 2$ 